\begin{tabular}{|c|c|c|c|}
\hline $\begin{array}{l}\text { Sample. } \\
\text { Ore-carnotite II. . . . . . . }\end{array}$ & $\begin{array}{l}\text { Grams. } \\
1.0009 \\
2.0005\end{array}$ & $\begin{array}{c}\text { Per cent. } \mathrm{U}_{8} \mathrm{O}_{8} \text {. } \\
6.755 \\
6.702\end{array}$ & $\begin{array}{c}\text { Per cent. } \mathrm{V}_{2} \mathrm{O}_{5} \text {. } \\
6.849 \\
6.526\end{array}$ \\
\hline Ore-carnotite III . . . . . . & $\begin{array}{l}1.0006 \\
1.0003\end{array}$ & $\begin{array}{l}4.873 \\
4.945\end{array}$ & $\begin{array}{l}5.128 \\
5.358\end{array}$ \\
\hline Ore-carnotite IV ........ & $\begin{array}{l}1.00045 \\
1.00025\end{array}$ & $\begin{array}{l}1.834 \\
1.728\end{array}$ & $\begin{array}{l}\cdots \\
\cdots\end{array}$ \\
\hline Ore carnotite $V \ldots \ldots \ldots$ & $\begin{array}{r}0.9994 \\
1.2004\end{array}$ & $\begin{array}{l}0.4094 \\
0.4205\end{array}$ & $\begin{array}{l}\cdots \\
\cdots\end{array}$ \\
\hline
\end{tabular}

\title{
THE SOLUBILITY OF SILVER CHLORIDE IN HYDRO- CHLORIC ACID AND IN SODIUM CHLORIDE SOLUTIONS.
}

\author{
BY WILLIAM EDWARD BARLOW. \\ Received August $\mathrm{I} 7,1906$.
}

IT Has been shown by Dudley ${ }^{1}$ that when sodium dioxide is fused in a silver crucible the metal is rapidly attacked, with the formation of a complex oxide.

In I902 I observed, in ignorance of Dudley's paper, the same action, and showed ${ }^{2}$ that when the melt is evaporated or heated with hydrochloric acid (as in the method of determining sulphur by means of fusion with sodium dioxide) the altered silver is converted into chloride, which dissolves (in amounts varying with the temperature and concentration) in the concentrated salt solution present. If the solution is then filtered, and allowed to stand, the greater part-but not the whole- of the silver chloride deposits on cooling. The barium sulphate precipitates from such determinations are almost certain to contain silver. When the solution is filtered hot, and barium chloride solution added before cooling, as in the ordinary sodium peroxide process for determining sulphur, the amount of silver in the barium sulphate may be considerable. In one case 0.03 gram silver chloride was extracted from such a precipitate. This would have occasioned an error of 0.2 per cent. in the sulphur content.

To ascertain the extent to which the reactions above mentioned go on under the conditions of a sodium peroxide fusion the following experiments were made:

I Am. Ch. J. 28, 62 (1902).

2 Inaugural Dissertation, Göttingen, June, 1903. 
(a) 22.5 grams of sodium chloride, an amount corresponding to the 5 grams of sodium peroxide used in a fusion, were dissolved in $200 \mathrm{cc}$. of boiling water, and silver nitrate solution was added to the hot solution until a permanent precipitate was produced. The liquid was then quickly filtered clear, and the dissolved silver was precipitated with hydrogen sulphide. The weight of silver sulphide found corresponded to $0.03 \mathrm{gram}$ silver chloride.

(b) The above experiment was repeated, using, however, 400 cc. of water. The silver chloride dissolved was 0.027 gram. Two or three drops of the silver nitrate solution gave a permanent precipitate in the cold solution. A little of this cold solution, filtered perfectly clear, gave a brown coloration with hydrogen sulphide, showing that small amounts of silver chloride dissolve in such solutions even in the cold.

(c) Twenty-three grams of sodium chloride in $400 \mathrm{cc}$. of cold water, with about $8 \mathrm{cc}$. of concentrated hydrochloric acid, dissolved 0.01 gram silver chloride in the cold.

Attempts were then made to estimate volumetrically the amounts of silver chloride taken up by various solutions of sodium chloride and hydrochloric acid. Silver nitrate solution (of known silver content) was added from a burette to the solution to be tested, until, with moderate stirring, a faint white cloud of silver chloride remained. The burette was read, the salt solution brought to $50^{\circ}$, and the addition of silver nitrate continued until a permanent precipitate was again produced. The titration was then made at about $90^{\circ}$ in the same solution.

The results of these titrations are tabulated below. In every case the same amount of sodium chloride was used, 23 grams, corresponding to the 15 grams of sodium peroxide used in a fusion. When acid was used it was present in the proportion of Io $\mathrm{cc}$. of the concentrated acid to $290 \mathrm{cc}$. of solution. The solutions marked with asterisks were of approximately the same concentration as the filtrate from a peroxide fusion as regards sodium chloride, although they contained somewhat larger amounts of acid.

The results from Ioo cc. in Series $A$ and $C$ are probably rendered low by the dilution of the solution with the 5 or $16 \mathrm{cc}$. of silver nitrate solution. In all other cases the dilution is small enough to have a negligible effect under the conditions described.

The silver nitrate solution contained 0.01485 gram of the salt 
per cubic centimeter, corresponding to 0.012525 gram silver chloride per cubic centimeter.

\begin{tabular}{|c|c|c|c|c|}
\hline \multirow[t]{2}{*}{$\begin{array}{c}\text { Volume of } \\
\text { solution. } \\
\text { cc. }\end{array}$} & \multicolumn{4}{|c|}{$\begin{array}{cc}\mathrm{About}^{20^{\circ}} \\
\text { cc. of } \mathrm{AgNO} \\
\text { solution needed. solution needed. solution needed. weight of } \mathrm{Ag} \\
\text { cc. of } \mathrm{AgNO}\end{array}$} \\
\hline & \multicolumn{4}{|c|}{ Series A. -23 grams of sodium chloride alone. } \\
\hline IOO & 2.50 & 7.10 & 15.70 & 0.1966 \\
\hline 150 & I. 15 & 2.30 & 9.80 & 0.1227 \\
\hline 200 & 0.50 & 2.00 & 7.60 & 0.0952 \\
\hline $300^{*}$ & 0.30 & 1.40 & 5.95 & 0.0745 \\
\hline $400^{*}$ & 0.15 & I.10 & 4.55 & 0.0569 \\
\hline $500 *$ & 0.10 & 1.00 & 4.20 & 0.0526 \\
\hline 700 & 0.10 & 0.90 & 3.90 & 0.0488 \\
\hline \multicolumn{5}{|c|}{ Series B.- $10 \mathrm{cc}$. of conc. $\mathrm{HCl}$ in each $300 \mathrm{cc}$. solution. } \\
\hline 100 & 0.05 & 0.12 & 0.35 & 0.0043 \\
\hline 150 & $\ldots$ & 0.18 & 0.70 & 0.0086 \\
\hline 200 & 0.10 & 0.25 & 0.90 & 0.0112 \\
\hline $300^{*}$ & $\ldots$ & 0.35 & I. 35 & 0.0169 \\
\hline $400^{*}$ & 0.20 & 0.50 & I.90 & 0.0238 \\
\hline $500 *$ & $\ldots$ & 0.60 & 2.20 & 0.0275 \\
\hline 700 & 0.20 & 0.75 & 3.20 & 0.0400 \\
\hline \multicolumn{5}{|c|}{ Series $\mathrm{C}$ - - Sodium chloride and $\mathrm{HCl}$ together. } \\
\hline 100 & 2.20 & 5.70 & r6.00 & 0.2004 \\
\hline I 50 & $x .50$ & 3.80 & ro. 50 & O. I 3 I 5 \\
\hline 200 & 0.80 & 2.90 & 9.30 & o. I I 65 \\
\hline $300 *$ & 0.40 & 2.10 & 7.50 & 0.0939 \\
\hline $400 *$ & 0.35 & I.5O & 6.70 & 0.0839 \\
\hline $500^{*}$ & 0.35 & I.80 & 6.80 & 0.0852 \\
\hline 700 & 0.45 & 2.00 & 7.70 & 0.0964 \\
\hline
\end{tabular}

In the following table the sums of the results of Series $A$ and $B$, at $90^{\circ}$, are placed side by side with the corresponding results of $\mathrm{C}$.

$\begin{array}{ccc}\begin{array}{c}\text { Volume of } \\ \text { solution. } \\ \text { cc. }\end{array} & \begin{array}{c}\text { Sums of results } \\ \text { of } A \text { and } B .\end{array} & \begin{array}{c}\text { Results of } \\ \text { cc. } \\ \text { series C. } \\ \text { cc. }\end{array} \\ 100 & 16.05 & 16.00 \\ 150 & 10.50 & 10.50 \\ 200 & 8.50 & 9.30 \\ 300 & 7.30 & 7.50 \\ 400 & 6.45 & 6.70 \\ 500 & 6.40 & 6.80 \\ 700 & 7.10 & 7.70\end{array}$

The figures show that the solubility of silver chloride in solutions of sodium chloride falls off (at a gradually diminishing rate) with diminishing concentration, and that the amounts of silver chloride dissolved in the acid are directly proportional to the volumes of acid (of fixed concentration) used. The increase in 
solubility near the end of Series $C$ is due to the larger amounts of acid present. The results of $\mathrm{C}$ correspond nearly enough with the sums of A and B to show that the effects of the sodium chloride and acid are independent. These facts become even more evident when the results are expressed in the form of curves.

It is clear that the use of a silver dish for sulphur determinations by fusion with sodium dioxide introduces complications. The removal of the dissolved silver is best effected by precipitation with perfectly pure hydrogen sulphide. Dilution to $400 \mathrm{cc}$, and filtering after cooling, does not suffice to remove all the silver. Dilution to a much larger volume would involve either a tedious evaporation over the alcohol lamp before precipitation with barium chloride or a considerable error: owing to the solubility of barium sulphate in the large volume of solution. It is simpler and more satisfactory to avoid the difficulty by using a nickel crucible or dish.

METALIURGICAL LABORATORY,

VIRGINIA POLYTECHNIC INSTITUTE.

[CONTRIBUTIONS FROM THE HAVEMEYER LABORATORIES OF COLUMBIA UNIVERSITY, NO. [24.]

RESEARCHES ON QUINAZOLINES (SIXTEENTH PAPER). SYNTHESIS OF 6-NITRO-2-METHYL-4-KETODIHY. DROQUINAZOLINES FROM 5-NITROACETANTHRANIL AND PRIMARY AMINES.'

By Marston Taylor Bogert and Ellen parmelee CoOk.

Received July 13 , 5906.

IN previous papers ${ }^{2}$ we have reported upon 5- and 7-nitro-4ketodihydroquinazolines. The following article contains a record of some experiments in the synthesis of derivatives of the 6-nitro isomer.

Dehoff, ${ }^{3}$ by the direct nitration of 2 -methyl-4-ketodihydroquinazoline, obtained a nitro derivative in which the position of the nitro group remained unknown until Thieme prepared the same substance by heating the ethyl ester of 5-nitro-2-acetamino-

1 Read at the meeting of the New York Section of the American Chemcal Society, May I I, Igo6.

${ }^{2}$ Bogert and Chambers: This Journal, 27, 649 (1905); Bogert and Seil : Ibid. 27, 1305 (1905); 28, 884 (1906); Bogert and Steiner : Ibid. 27, I327 (1905).

${ }^{3}$ J. pr. Chem. [2] 42, 347 (1890).

* Ibid. [2] 43, 473 (189I). 